\title{
生コン製造・運搬
}

\author{
吉 兼亭*
}

生コンクリートの JIS 規格は, JIS A 5308 レディーミ クストコンクリートとして 1953 (昭和 28) 年に制定され, 1965 （昭和 40）年に工業標準化法に則り生コン工場の JIS マーク表示制度がスタートし，翌 1966 (昭和 41）年 から生コン工場の認定審査が始まった。その後, 2005 (平成 17）年には工業標準化法の改正により国による工 場認定から，民間の登録認証機関による製品認証へと移 行した。JIS A 5308 は 12 回の改正を経て現在に至って いる。認定・認証による品質の信頼性向上に向けてこの ような努力がなされてきたわけであるが，ともすれば生 産者はJIS マーク品として適合しておればという思考か ら，また購入者も JIS マークが表示されていればという 安心感から, さらには生コン業界の協同組合による共同 販売制度により，品質向上に向けての努力・意識が必ず しも高くない。

このような状況下にあって, 度重なる JIS 規格の改正 により品質の向上が図られてきたが，そこには関連業界 への影響もあり, 一方的にJIS A 5308 の改正では対応 できない事項も少なくない。また，生コンクリートの製 造における品質管理に関しては, 試験をしてもリアルタ イムにフィードバックできないにもかかわらず試験記録 が重視される弊害も一部では生じている。特に生コンの 材料の中で最も大きな容積を占める骨材についてその傾 向が認められる。品質管理とは試験するのが目的ではな く, 試験はあくまで手段に過ぎず, その目的は品質の安 定・向上にあるが，そのことがないがしろにされて，極 論すれば人手をかけずに機械・装置に任せられるところ まで, 踏み込もうとしていないことで技術の進展が見ら れない。人手をかけて試験をし，その結果をフィードバッ クすることにより品質の修正を行っても, タイムラグの ために実効性が低い手段をとるよりは，機械・装置化に より人手をかけなくても品質が安定する方法をとるべき ではなかろうか。

人の能力を否定するのでなく，効果のないことに人手 をかける無駄を省き, 機械化により品質の安定・向上を 図ることの必要性を認識して頂きたく，人手は技術の進 展に向けられることを望む。以下この点を中心に種々の 見解を述べる。

* よしかね・とおる/NPO 法人 コンクリート技術支援機構 副理事 長（名誉会員）
なお，本稿の末尾に，昨今のコンクリートをめぐるト ラブルを知るにつれ，コンクリート造りの基本として示 されている吉田徳次郎博士の言葉を引用させていただ き，良いコンクリートは人の心からの取組みが大切であ ることの認識が深められればと痛感する次第である。

\section{1. 骨材に関して}

骨材は生コンクリートの材料中で最大の容積を占めほ ほ 70\%に達する。しかし生コンの材料で JIS 認証品でな くて使用できるのは一部のスラグ骨材を除いた骨材とセ メントである。このうちセメントは我が国では JIS 認証 の取得は行われていないが, 古くから JIS 規格がありそ れに則って安定した品質で製造されており，別段問題が あるわけではない。一方, 骨材は砕石・砕砂には JIS 規 格があり JIS 認証の対象ではあるが，現状では砕石・砕 砂を生産する約 1400 工場のうち JIS 認証を取得してい る工場はわずか 100 工場程度であり 1 割にも満たない。

その上, 天然骨材 (河川・山・陸・海産などの砂利 · 砂）を生産する工場は 3 千数百とみられているが, それ らは認証の基となる JIS 規格すらなく JIS 認証の対象と はなっていない。すなわち, 合計約 4000 工場とみられ る骨材生産工場の内 $2.5 \%$ の工場しか JIS 認証を取得し ていない。この結果, 我が国で生産されている骨材の大 半は, その製造における品質管理は全く義務付けられて いないことになる。ほとんどのケースで生コン側の要求 品質で扱われているにすぎない。もちろん，生コンの JIS 規格（JIS A 5308）には骨材に関する規定がありそ こには品質基準が示されているが，骨材生産者に対して 直接規定しているものではない。

したがって, 骨材生産者側で品質管理のための試験を している工場は皆無に近く，品質向上に関しての関心が 非常に低い。そのため生コン側で品質向上を図るにしても 以下の問題点があり簡単に生コン側で解決できる問題で はない。しかも，これらは全てが独立した問題ではなく， いくつかは互いにリンクしている問題でもある。なお, こ れらについて詳述するにはスペースがないので，それぞれ の要点と見解を簡単に述べるとともに参考資料を示した。

\section{1) 粒度分離問題 :}

・図-1 にコンベアからの落下前方と後方で著しい 粒度分離が生じている現象を示す ${ }^{1), 2) 。 ~}$ 

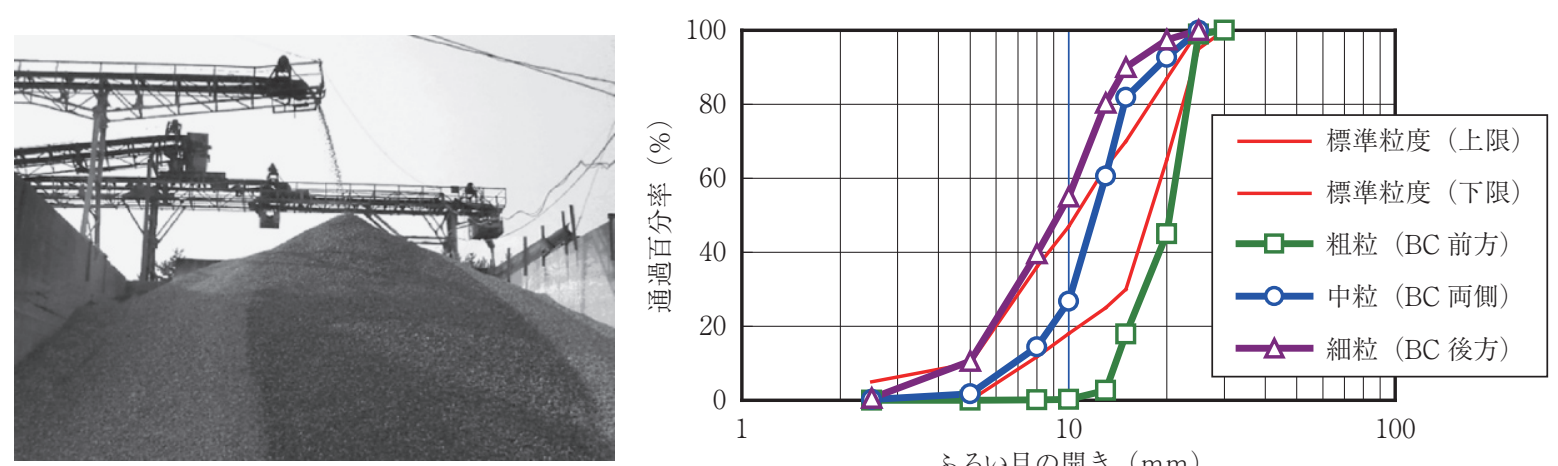

図-1ストックヤードにおける粗骨材の分離 ${ }^{1}$

・最大粒径と最小粒径の差が 3 を超えると分離しや すい゙（粗骨材に過小粒が含まれ分母は $5 \mathrm{~mm} て ゙$ なく $2.5 \mathrm{~mm}$ になる。例えば $25 / 2.5=10$ となり 著しく分離する)。

・このような骨材が生コン工場に運び込まれると粒 度変動が著しくなる $($ 図-2 参照)

・生コン工場にはアスファルトプラントのような粒 度コントロール設備がない。

・粒度試験によるフィードバックはリアルタイムに はできない。分離防止の方が先決。

・ワーカビリティーおよび単位水量への影響が大き い2（特にコンクリートの分離に影響する）。

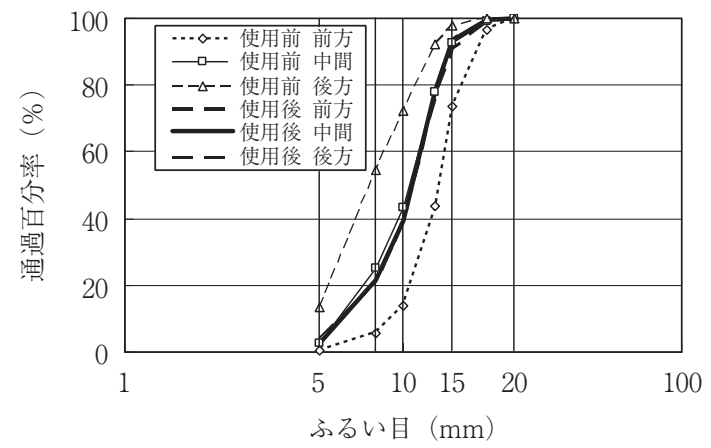

（a）粗骨材の場合（細線：使用前, 太線：使用後)

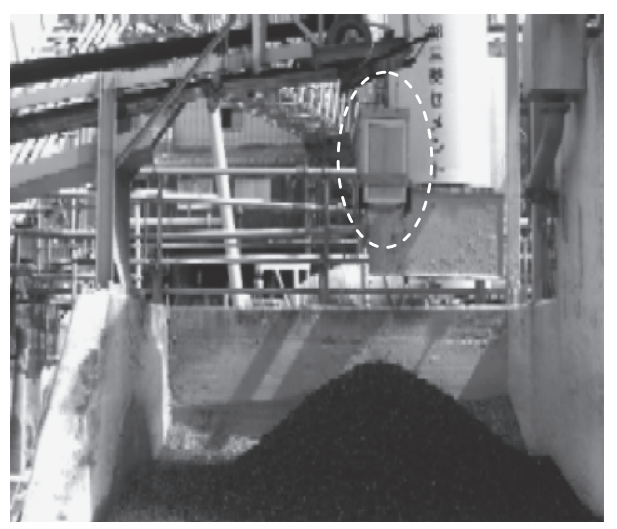

注）上図からも分かるように，分離防止装置がない場合には， 落下の前後左右で著しく分離している(細線) が, 分離防止 装置を介すると，粒度分布は前後左右とも一つの線（太線） に重なるのが分かる。

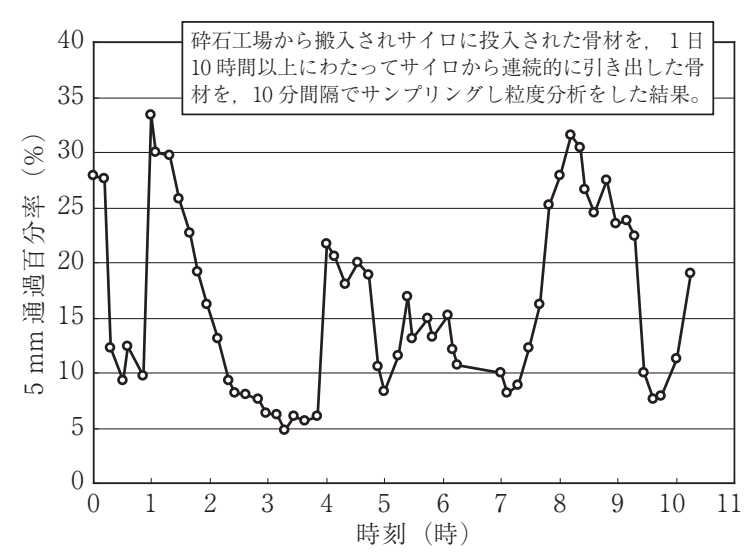

図-2 1305 砕石のサイロからの連続引出における粒度の変動

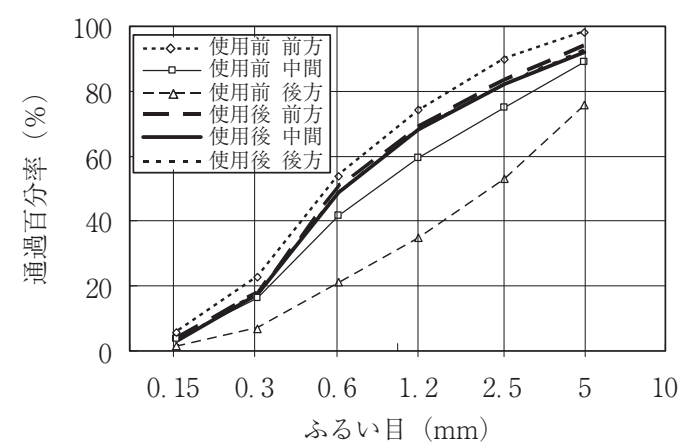

（b）細骨材の場合（細線：使用前, 太線：使用後）
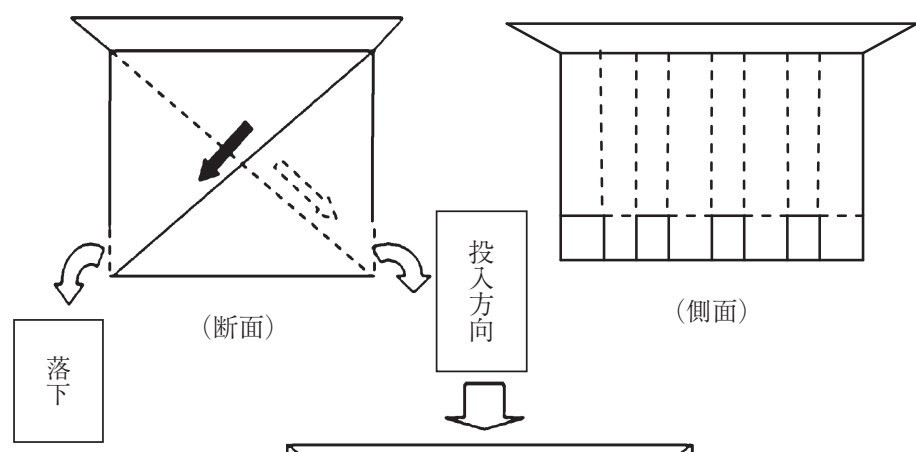

（側面）

(平面)

図-3＼cjkstart分離防止装置とその効果 ${ }^{5,6}$ 
・分離防止装置の骨材生産工場および生コン工場で の設置が必須（砕石の JIS でも規定なし）。

・分離防止装置の提案とその効果 ${ }^{5)}$, 6) を図-3に示す。

2）連続粒度と 5 2.5 mm 粒分（過大粒・過小粒問 題を含む）：

・いずれもスランプ, ワーカビリティー, 単位水量 に大きな影響を及ぼす成を。

・粗細骨材合成粒度曲線（図-4 参照）のパターン がワーカビリティーを左右する ${ }^{1)}$,2)。

・連続粒度ではプラスチックでワーカブルなコンク リートは造れない票（図-5参照）。

・天然骨材でも砕石・砕砂でも，粗細骨材の分級前 は連続粒度。

・最大骨材寸法 $25 / 20 \mathrm{~mm}$ のプラスチックでワーカ ブルなコンクリートにとっては $5 \sim 2.5 \mathrm{~mm}$ 粒分

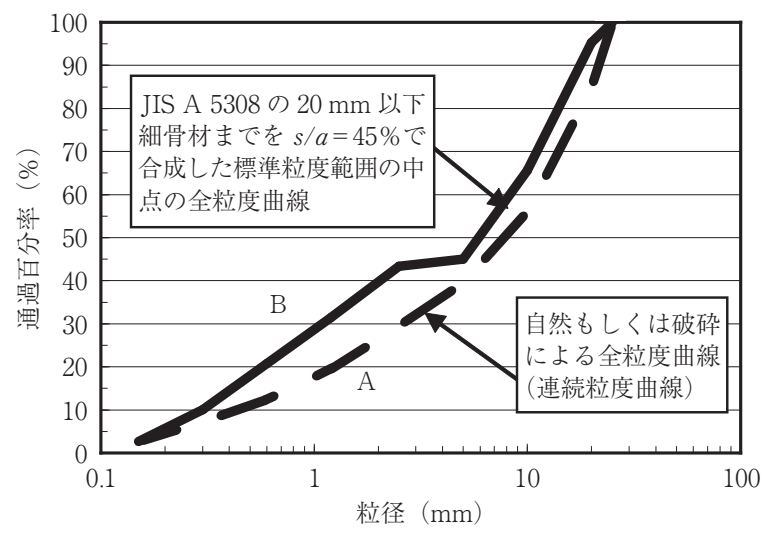

図-4 合成粒度曲線のパターン1
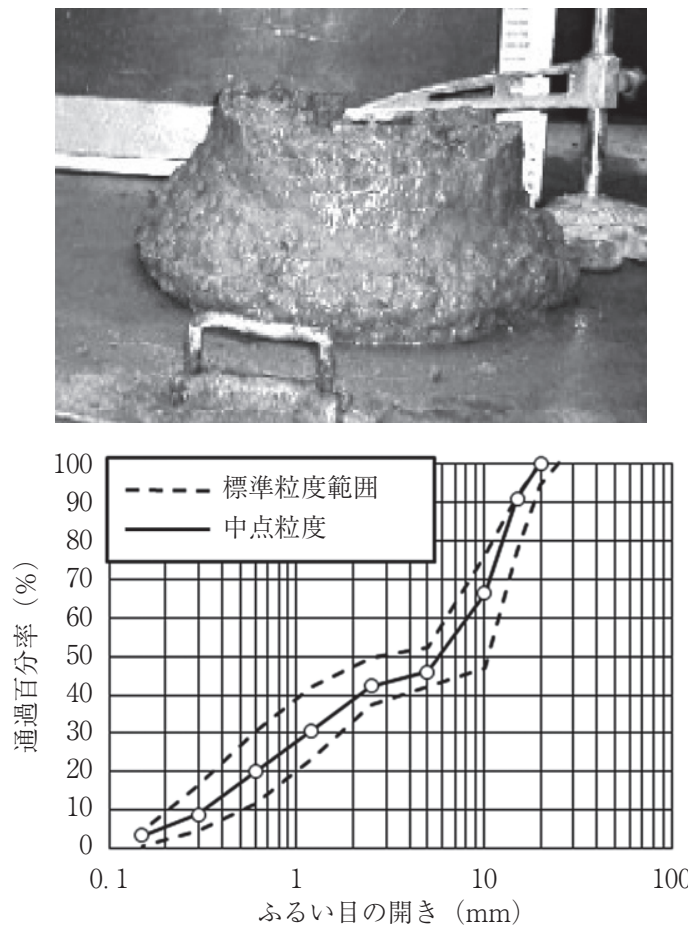

(標準粒度範囲の中点粒度)
は不要 ${ }^{1,2)}$ 。ワーカビリティーの向上，単位水量 の削減にはこの問題を重視すべきである。

3) 粗骨材 2 分割方式:

· 2505 の 2515 と 1505 への分割, 2005 の 2010 と 1005 への分割などで分離の影響度の低減。

・全国的な実施率は $28 \%$ 程度 $^{7)}$ 。更なる普及が望ま れる。

・普及のために 2505 や 2005 の区分を JIS 規格から なくせないか（予告期間は必要だが）。

・分割使用でなければ，粒度試験を 1 日に数多く やっても粒度変動に対しリアルタイムのフィード バックによる配合修正は無理（図-2参照）。まし てや通常の 1 回/日の試験では全く無意味。

・分割しても分離がなくなるわけではない(4).5)。分 離防止と分割使用は切り離せない。

4）アルカリシリカ反応試験結果の信頼性（サンプリ ングの公正性の欠如）：

・反応性試験のサンプリングは生産者任せ。都合の 良い結果のみが報告される信憑性の低さ。

・我が国の地層は複雑に入り組んでいて，一つの採 掘場や切羽でも反応性「あり」と「なし」とが混 在しているケースが多い。性善説頼りが逆に信憑 性を失う。

・単位セメント量 $400 \mathrm{~kg}$ 以下ではコンクリートの アルカリ総量は $3 \mathrm{~kg}$ 以下となる。しかも単位セ メント量 $400 \mathrm{~kg}$ 以下のコンクリートは我が国全体 で $90 \%$ 以上。信憑性のない試験に頼る必要なし。
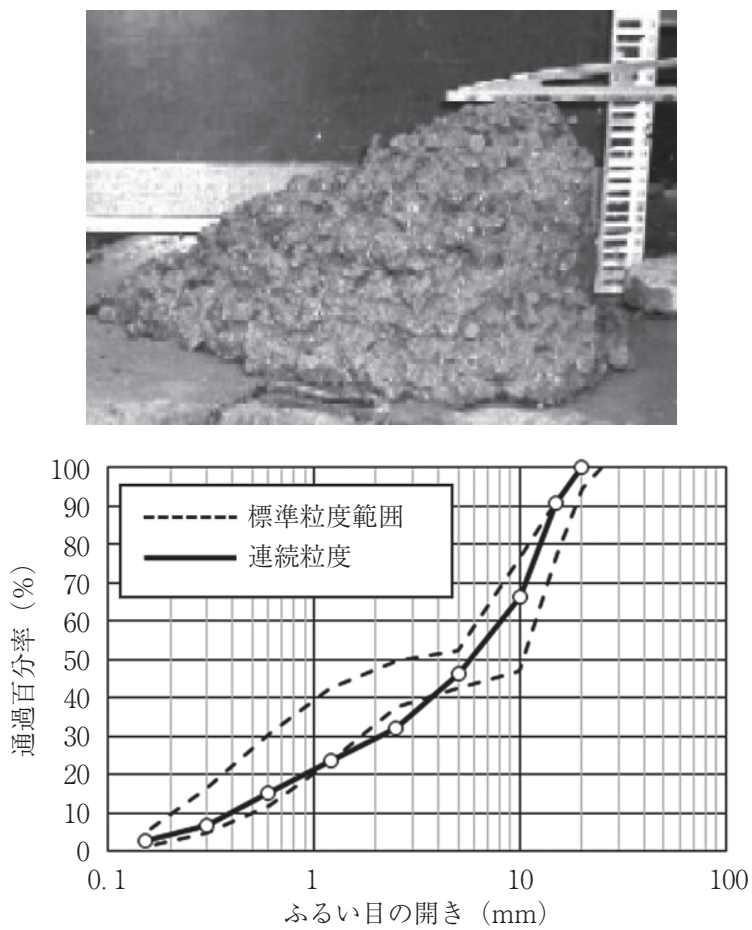

(連続粒度：5 2.5 mm 粒分が多い)

※左右は全く同じ配合であるがスランプは左：20.5 cm で状態良好，右：15 cm で分離・崩壊状態

図-5＼cjkstart標準粒度範囲の中点粒度と連続粒度のコンクリートのスランプ状態 ${ }^{1}$ 
・採掘場全体が無害を主張するならば，第三者機関 がサンプリングまで直接行い証明する方法である べき。もちろんのこと定期検査も必要。

5）細骨材表面水率自動測定装置への過信（短絡的な 思考)：

・細骨材の表面水率が正確に測られても，1） 3) の指摘事項への対応が完璧にできていて，かつ安 定状態でない限りスランプは安定しない（現状で はほとんどできていない)。

·表面水率自動測定装置の測定誤差（水量換算値） は，水の計量の許容值に比べて数倍以上である。 したがって単位水量の管理上も精度が良くない。 普及率は減少傾向で H 25 年度は $7 \%$ に過ぎない6)。 表面水率自動装置に頼るよりも 1)～3）の指摘事 項への管理強化の方が効果的である。

6）乾燥収縮における石灰石砕石への盲目的依存（資 源・環境・コスト問題)：

・資源保護・環境保全（問題：運搬距離増加による $\mathrm{CO}_{2}$ 発生量の増加）・コスト面で問題多し。

·石灰石以外でも $8 \times 10^{-4}$ 以下の骨材が Max $20 \mathrm{~mm}$ で93\%が，同 $25 \mathrm{~mm}$ で 95\%が存在する ${ }^{8)}$

・試験結果への信頼性よりも石灰石を使用の方がリ スクは小さいという安易な解決策の蔓延。

·工事入札における技術提案制度も石灰石使用に拍 車をかけている。

2. 配合に関して

1) 目標単位水量の設定の問題点：

正規分布する品質の特性值にあっては，製造の目 標值とはその母集団の平均值であり，品質管理に おいては, 標準偏差の低減により平均值（目標值） を無駄に大きくしないことが，第一義的目的。

目標設定の実態は，骨材粒度およびコンクリート 温度がベストコンディションで，かつ運搬時間ゼ ロの状態で試し練りにより確認されたものが採用 されている。したがって実際の単位水量は図-6 に示すようにほとんどプラス側にしか変動しない ことになる。

国土交通省の検査基準では，目標值が母集団の平 均值に対して定められていることが前提となって いて許容值がさで与えられている。

・検査ではほとんどプラス側の結果が得られ，した がって単位水量の実測平均值は目標值とは乘離し ているケースが大半である。特に単位水量迅速測 定方法のモルタル法では，サンプリングによる偏 りで測定值が真の值よりマイナス側にでるので偏 りの補正は必須である。

・モルタル法での単位水量の迅速測定試験で偏りの 補正をしない場合は, 絶対值の判定を行うのでは
なく，相対的なデータとして変動の幅を把握する のに役立てる方が有効であろう。

・目標単位水量の設定は, 骨材は過小粒・過大粒率 を含め出荷コンクリートの実績の平均粒度で設定 すべきであるが，その実質の平均粒度さえ把握さ れていない。

2）スランプの上限要求と “打込みの最小スランプ” に関して :

・加水問題が少し形を変えて曼延しているのが “上 限要求”である。

・“上限要求”とは，図-7に示すように，スランプ の判定基準は土 $2.5 \mathrm{~cm}$ が許容されるが，そのう ちプラス側のみが許容されて, マイナス側は受け 取りを拒否するという要求である。

・スランプは骨材の粒度，材料温度，コンクリート 温度，運搬時間の変化などに加えて，スランプ試 験の誤差から言ってこれ以上小さくするのは，技 術的に全く不可能ではないにしても，全てのコン クリートにおいて粒度や粒形に関する骨材の JIS

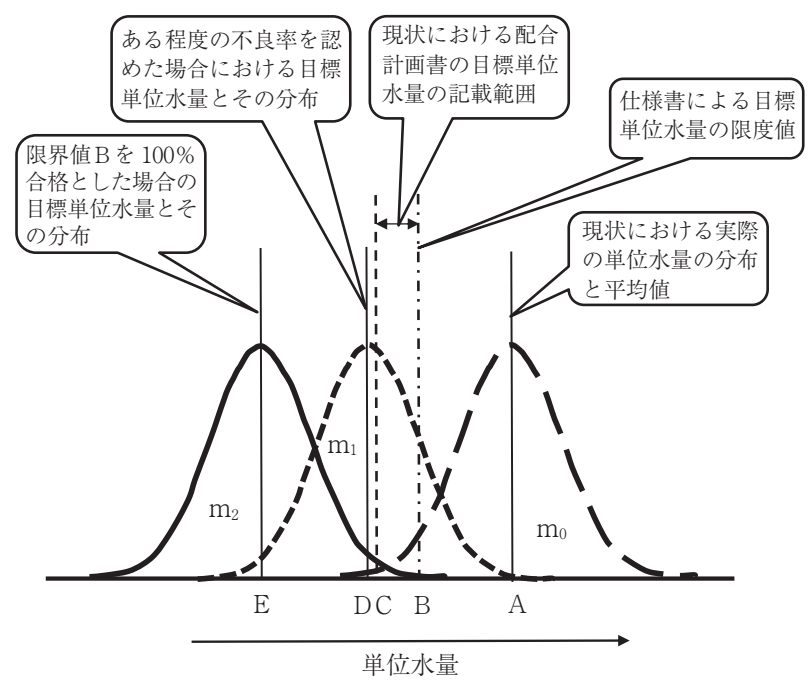

図-6 単位水量の位置づけ

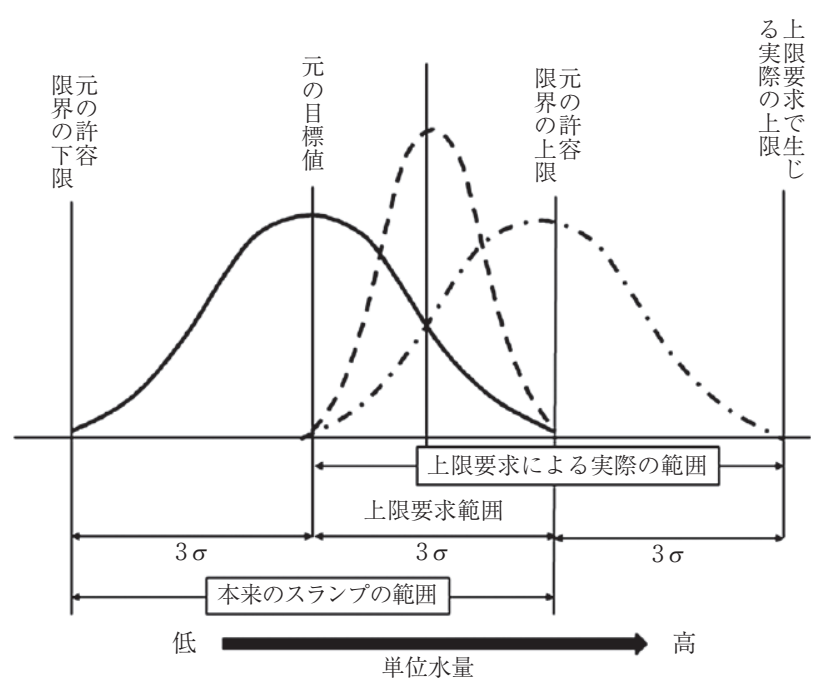

図-7 上限要求の概念図 


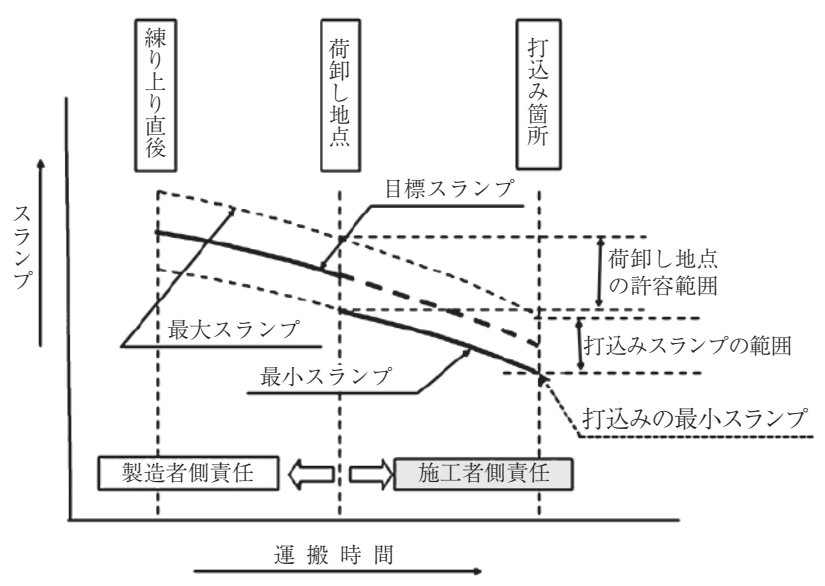

図-8 打込みの最小スランプの概念図

規格における品質基準や表面水率の調整，さらに 製造方法からして大幅に改正・改善しなければな らない。単に生コン業界のみならず骨材生産にも 及ぶ問題である（中にはスリップフォームコンク リートのように工法上で制約の厳しいコンクリー 卜もあるが，人海戦術での対応で要求に応えてい る)。単に人の努力に頼るのみでは良くならない。 ・実態は図に示すように単に目標值が高くなったこ とに過ぎず， $[18 \sim 18+2.5 \mathrm{~cm}]$ の上限要求のコ ンクリートとしては，実際は $[20.5 \pm 2.5 \mathrm{~cm}]$ の コンクリートが納められており，20.5 cm を超え るコンクリートに関しては受入れ側に支障がある わけではないので黙認しているに過ぎない。

・この問題を避けるために, 土木学会では図-8に示 すように“打込みの最小スランプ”の定義を設け， そこから遡って荷卸し地点に打ける目標スランプ を定める方法が提案され，コンクリート標準示方 書にも明示され，施工方法に応じた打込みの最小 スランプの選択肢が具体的かつ詳細に示された。

・この考え方が普及することが望まれる。しかし発 注者からは，コンクリートコストが高くなるとの 抵抗が少なくなく，それが普及の足かせとなって いる。コストダウンは確かに大切なことではある が, 信頼性, 耐久性の高いコンクリート構造物を 造ることはそれ以上に大切なことである。

3）細骨材率過剩配合の問題：

・環境保全問題や資源枯渇により，天然骨材から砕 石・砕砂への転換が進みその結果としてワーカビ リティー確保のため,コンクリート配合に扔ける 細骨材率が増加するのはやむを得ないが，それの みでなくポンプ打設における配管での閉塞のク レームを避けるため, 細骨材率が高くなる傾向が 見られる。

·粗骨材中の過小粒，細骨材中の $5 \sim 2.5 \mathrm{~mm}$ 粒分 が増加していることで，コンクリートのワーカビ リティーが悪くなるのを抑制するのに細骨材率が
引き上げられている。このためスランプの大きい コンクリートでは真の細骨材率が $60 \%$ 近くにな ることも珍しくない。

・コンクリート中のモルタル分が増加することで単 位水量が増加し，それにより乾燥収縮率が大きく なることは明らかである。従来, 乾燥収縮率や, アルカリシリカ反応などは容積率の大きい粗骨材 が主役として扱われてきたが，その立場も高スラ ンプのコンクリートに拍いては入れ替わっている。 ・コンクリートの配合設計では, 単位水量が最小に なるように骨材の組み合わせを定め，次に強度に 対応する水セメント比を決めることであると, 吉 田徳次郎博士も指摘 ${ }^{3}$ されているが, 現状は最初 に細骨材率ありきの様相である。

改善策として例えば，砕石・砕砂に抒ける粒形判 定実積率の向上，粗骨材の最大粒径が $25 / 20 \mathrm{~mm}$ のコンクリートに用いる骨材（ただし，転圧コン クリートは除く）に打ける 5 〜 $2.5 \mathrm{~mm}$ 粒分の排 除（5 2. $5 \mathrm{~mm}$ 粒分は $2.5 \mathrm{~mm}$ 以下に破砕して 細骨材に混合する), 高性能 $\mathrm{AE}$ 減水剂の活用が 挙げられる。

3. 試験に関して（ワーカビリティーの表示，記 号化, トレーサビリティー)

・良いコンクリートとはプラスチックでワーカブル であることとされているが，コンシステンシー （軟らかさ，変形または流動に対する抵抗性）は スランプ值で数值化されているが，ワーカビリ ティーおよびプラスティシティは数值化されてい ない。しかし、スランプの形や広がりを注意深く 観察すれば, フレッシュコンクリートの品質判断 に十分役立つ。

・「JIS A 1101 コンクリートのスランプ試験方法」 にはそのような記述はまったくなく， 単にスラン プした頂面の下がり高さを測定する記述があるの みで，わずかに「コンクリートがスランプコーン の中心軸に対して偏ったり，崩れたりして形が不 均衡になった場合は別の試料によって再試験をす る」とあるが，コンクリートの状態の判定につい ては何も触れられていない。

・全国生コンクリート工業組合連合会試験方法 （ZKT-201）ではスランプの形状に応じたスラン プの測定の仕方について図示しているが，状態の 判定には触れていない。

図-9にスランプの形状によりコンクリートのワー カビリティーを記号化し判定する方法を提案す る。この記号をスランプ試験值に併記すれば，コ ンクリートの状態の記録に役立つことになり， ト レーサビリティーにも役立つ。実験にもこの方法 
スランプの状態の表し方

\begin{tabular}{|c|c|c|}
\hline 記 & \multicolumn{2}{|r|}{ コンクリートの状態 } \\
\hline $\mathrm{N}$ & Normal & $\begin{array}{l}\text { 標準的プラスティックでワーカブ } \\
\text { ルな状態 }\end{array}$ \\
\hline $\mathrm{P}$ & Over plastic & $\begin{array}{l}\text { 粘性の高い状態/オーバープラス } \\
\text { ティック }\end{array}$ \\
\hline $\mathrm{S}$ & Segregation & $\begin{array}{l}\text { 頂部のフラットな面がなく, 外輪 } \\
\text { の輪郭が見られないもの }\end{array}$ \\
\hline $\mathrm{F}$ & Fall down & $\begin{array}{l}\text { 頂部のフラットな面が一部もしく } \\
\text { は全体が崩落した状態 }\end{array}$ \\
\hline $\mathrm{C}$ & Crack & $\begin{array}{l}\text { 固練りの側面にひび割れや豆板状 } \\
\text { のものが見られる状態 }\end{array}$ \\
\hline I & Incline & $\begin{array}{l}\text { 頂部のフラット面が著しく傾いた } \\
\text { 状態（最高点と最低点との差が } \\
3 \mathrm{~cm} \text { 以上） }\end{array}$ \\
\hline U & Un symmetry & $\begin{array}{l}\text { フローの形が円形と著しく異なる } \\
\text { か, 頂部のフラットな面の中心軸 } \\
\text { とフローの中心軸との偏心距離が } \\
\text { 著しく大きい状態 }\end{array}$ \\
\hline
\end{tabular}
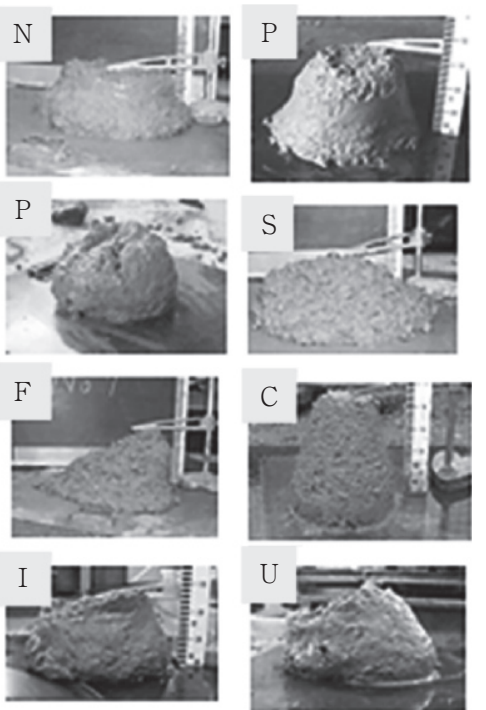

図-9 スランプの状態の表し方 ${ }^{9}$

を利用すれば写真の記録よりも簡便でかつ過去の データと併せて評価しやすくなる。フレッシュコ ンクリートの状態の良し悪しは, コンクリート構 造物の出来具合にも関係が深いだけに，生コンク リートの製造者側で十分に活用されたく思う。

4. 製造・運搬に関して

1）計量印字記録の活用と計量精度の向上策（動荷重 検査と過不足計量の処置について）:

・購入者からの要求があれば計量印字記録の提示が JIS 規格で明示されたので，生コン工場における 計量印字記録装置の設置は非常に進んで，普及率

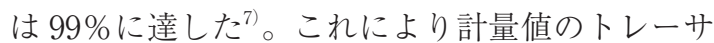
ビリティーが進んだ。

・動荷重検査では連続 5 バッチを対象に，全数合格 を基準として行われている。この検査で表示值と 記録值がずれた場合には補正するとされている が，ランダムで土にずれる現象に対して補正の 方法はなくかえって混乱を招くことになる。した がって，検査対象はあくまで設定值と記録值との 差であり，表示の整合性は合否判定でなく確認で 良い。

・計量印字記録は製造したすべてのコンクリートに ついて記録されているわけであるから，そこから 任意の連続バッチを抜取検査し，合否判定は生産 者危険率 $5 \%$ ，購入者危険率 $10 \%$ という一般的 な統計的基準に基づき, “JIS Z 9002 計数基準型 一回抜取検査”方法を適用することとし，実態調 査における不良率から合否判定条件を決めること が統計的にも合理的であろう。

・計量システムに関してはもう一つの提案がある。 それは，過・不足計量に関する扱いの問題で，現
状ではどちらの場合も手動で過・不足分の調整を 行うこととされている。このうち不足分に関して は追加分を計量用のゲートで操作をするのでそれ 程の難しさはないが, 過計量ともなるとミキサへ の投入の際の排出途中でゲートの開閉で調整する ことになるが，計量槽の残量がわずかな状態で排 出を止めることは, 排出ゲートの開口面積が大き く瞬間的な落下量が多いだけにコントロールが上 手くできない。加えて残量を自記計量記録紙に手 書きで併記し，責任者の承認印が必要だとされて いる。全く現実離れした作業であり信頼性も担保 できない。それよりは，過不足の調整は同一積み 込み車両 1 台分の 2 バッチ目で調整するソフトで 対処することの方が合理的である。すなわち 1 バッチ目の誤差を 2 バッチ目で調整し，あとは 1 台分のバッチ数だけ繰り返せば良いわけである。 こうすれば, $\{1$ 台分の所要バッチ数 -1$\}$ 回分だ け調整の機会がある。ただし，1台分 1 バッチの 大型ミキサを有する工場もごくわずか存在する が，その場合は計量值が大きいだけに許容の絶対 值も大きく機械的なコントロールが難しくないよ うである。この方法は 1965 年頃には既にアメリ カで実施されていた，そのことを JIS 改正の折に その提案をしたが，バッチ内で完成していないの は認められないと拒否された。現在の JIS A 5308 では 1 台分の計量值から求めた各材料の単位量を 納入書に記述することを推奨しているのであるか ら，本提案の方法で支障がないものと思われる。 ぜひとも再検討を願いたいものである。

\section{2）運搬・納入の GPS による管理}

車両位置情報が GPSにより容易に確認ができること になってきたので，生コンの納入におけるアジテータト 
ラックの運行管理を携帯電話と併せてより効率的に行え るシステムが導入され始めた。アジテータトラックの位 置情報はもとより，運搬経路における交通状況，荷卸し 地点到着時刻，荷卸し待ち時間，荷卸し終了時刻など情 報を随時工場に連絡し，それを基に効率的に配車台数を 設定し，輸送効率を高め合理的な運行管理が行われる。 さらに出荷管理とリンクすることにより事務効率が図ら れるようになる。固定電話と黒板で管理していたのと比 ベれば効率の向上は比べ物にならない効果であろう。

1965 年頃のアメリカのヒューストン市における一会 社の例であるが，10 工場ほどの出荷業務と材料手配を， 固定電話の時代にオフィスの一部屋で 10 工場分の集中 管理を行っていた。今ならば共販における共同事業とし てこの GPS システムを導入し，組合事務所で出荷・運 行の集中管理を行えば，出荷業務の集約と AT 車の運転 効率向上でコストダウンにも寄与することになる。共販 事業であるのならそこまで考えるべきではなかろうか。 一つの共販組織を一つの会社組織と考えれば実行可能で はなかろうか。

\section{5. まと め}

上記のほかに，JIS 規格における製造方法の性能規定 化，JIS 規格の品質のグレードの設定，共販体制と生コ ン技術の停滞などについても触れたかったが紙面に余裕 がなく割愛した。

以上, 多くの課題についての現状とその対応について 述べてきたが，個々の課題が独立しているのでなく，多 くが複雑に絡み合い, 骨材などは生コン業界のみで解決 のつかない事項もあるが，真剣に時間をかけて取り組む のならば実現不能なことではない。人はともすれば安易 な道を求めたがるので，先に取り上げたように，人がや らなければならないことができてないケースも少なくな い。実現のために負担がかかるのを避けたがり，実行に 努力を払おうとしない習性がある。その一方で，フィー ドバックができない無意味な品質管理試験も存在してい
るにもかかわらず，問題解決のための他の手段を取ろう ともしていない。試験は品質管理の手段に過ぎず，品質 向上に効果がなければ他の手段を講じるべきである。

このような問題の解決を図る事業の推進には，関連業 界および業界内のコンセンサスを得ることも重大な問題 であるが，何にもまして業界団体の強力なリーダーシッ プが求められる。

終わりに吉田徳次郎博士の次の言葉を引用する。

「良いコンクリートも，セメント，水，骨材を練り混 ぜたものであり，悪いコンクリートも，セメント， 水，骨材を練り混ぜたものである。両者の差は，コ ンクリートについての知識と施工についての, 正直 親切の程度の差からおこるものである。よって，良 いコンクリートを造るには，セメント，水，および 骨材のほかに，知識と正直親切を加えなければなら ないことになる。」

技術が進歩しても“正直親切”は何にもまして欠くこ とのできない要素である。

\section{参考文献}

1）吉兼 亨：コンクリートの信頼性向上を目指して（生コンの単位 水量について考える), 第 287 回コンクリートセミナーテキスト, pp.6～20，(社セメント協会，2002.2.14

2）吉兼 亨：良いコンクリートの原点（単位水量の管理）, pp.20 67, セメントジャーナル社, 2004.3

3) 吉田德次郎：コンクリートの話（コンクリート技術の移り変わり）, コンクリートライブラリー第 1 号, pp.5〜 7, (社土木学会, 1962. 5

4）吉兼 亨ほか：自動配合管理システムによる加熱アスファルト混 合物の配合管理，舗装 $23-3 ，$ p.33，建設図書， 1985.5

5）吉兼 亨ほか：骨材の粒度分離がコンクリートの配合に及ぼす影 響と分離防止，骨材の品質と有効利用に関するシンポジウム論文 集, pp.63〜 72，(社)日本コンクリート工学協会, 2005.12.9

6) 吉兼 亨：骨材の粒度分離を防ぐ提案，砕石 No.262, pp.13〜21, (社)日本砕石協会, 2009.10

7）全国生コンクリート品質管理監查会議：平成 25 年度全国統一品質 管理監查結果報告書, p.17, p.18, p.38

8）全国生コンクリート工業組合連合会・技術委員会：乾燥収縮に関 する実態調査報告書 (平成 24 年度), 新技術開発報告書 No.42, pp. $29 \sim 31$, 平成 25 年 3 月

9）吉兼 亨：2）の文献 p.13，表-1に写真を併示した。 